\title{
Conodont biostratigraphy of the Crawford Group, Southern Uplands, Scotland
}

Howard A. Armstrong, Department of Geological Sciences, University of Durham, DH1 3LE, U. K.

James D. Floyd, British Geological Survey, Murchison House, Edinburgh, EH9 3LA, UK

Lu Tingqing, Institute of Petroleum Geology, Nanchong, P. R. China.

Hugh F. Barron, British Geological Survey, Murchison House, Edinburgh, EH9 3LA, UK

\section{Synopsis}

Extensive new conodont collections from the Crawford Group, the oldest succession in the Southern Uplands of Scotland, support the previously documented biostratigraphical ages for the included formations. The Raven Gill Formation is lower Whitlandian, Arenig (comparable in age to the Dounans Limestone in the Highland Border Complex) and the Kirkton Formation is latest Llandeilian to Aurelucian, Llanvirn to Caradoc in age. It is concluded that there is a significant stratigraphical gap within the Crawford Group. The restricted and probably faultbounded nature of the Raven Gill outcrops suggests that these may represent olistoliths within a mélange of Llandeilian to Aurelucian age. The chert-bearing succession of the Northern Belt of the Southern Uplands thus represents the juxtaposed sedimentary records of two entirely separate basins - the oldest pre-dates the Grampian assembly of the Laurentian margin, and the younger, the Northern Belt Basin sensu stricto, entirely post-dates this event.

Keywords: Conodont, Arenig, Llanvirn, Caradoc, Southern Uplands. 


\section{Introduction}

The Crawford Group is the oldest succession in the Northern Belt of the Southern Uplands. The historical but limited conodont biostratigraphical evidence suggests that there is a major stratigraphical gap between the Raven Gill Formation, of mid-Arenig age, and the Kirkton Formation of latest Llanvirn to early Caradoc age (Floyd, 2001 for a review). Remapping of the 1:50 000 Sheet 15E (Leadhills) by the British Geological Survey (BGS) over the last few years has brought to light a number of additional conodont-bearing chert localities within the Crawford Group that could potentially fill this stratigraphical gap. The aim of this study was to document the new collections, extend the historical dataset and test for stratigraphical continuity within the Crawford Group.

The thin, predominantly hemipelagic succession of the Crawford Group has provided the principal evidence for the Northern Belt forming part of a fore-arc accretionary prism (McKerrow et al. 1977; Leggett et al. 1979). This model relies on continuous accretion from the Arenig into the Silurian. Alternative models (see Smith et al. 2000 for a review), consider the Northern Belt as a back-arc basin (Hutton and Murphy 1987; Morris 1987; Stone et al. 1987) or as an extensional basin adjacent to the continental margin (Armstrong et al. 1996). The existence of a stratigraphical gap spanning much of the Lower Ordovician within the Crawford Group has significant implications for dating the onset of deposition in the Northern Belt Basin and, in particular, the accretionary prism model for the formation of the Southern Uplands.

\section{Stratigraphical Context}

The Crawford Group crops out extensively within the structurally complex, 1.8 km wide Leadhills Imbricate Zone (LIZ), as faulted repetitions of volcanic rocks, 
Armstrong et al.

Draft 9, 6233 words

chert, black shale and greywacke (Hepworth 1981, Hepworth et al. 1982, Leggett 1978, Leggett and Casey 1982). The LIZ lies immediately to the north of the Leadhills Fault (Fig. 1, Leggett et al. 1979, Armstrong et al. 1999). At least some of the greywackes belong to the Kirkcolm Formation (= Abington Formation of Hepworth 1981, Hepworth et al. 1982) and the black shales are assumed to represent parts of the Moffat Shale Group either beneath or interleaved near the base of the Kirkcolm Formation.

Floyd (1996) proposed that the Raven Gill Formation should be restricted to rocks of proven Arenig age and followed Hepworth (1981) in assigning the more extensive development of grey and red cherts, red and green siliceous mudstones and lavas in the LIZ to the Kirkton Formation (Fig. 2).

\section{Raven Gill Formation}

The Raven Gill Formation is known from only three closely grouped, probably fault-bounded, exposures within the LIZ (Figs 1 and 3, Table 1). Floyd (1996), following Hepworth (1981) and Hepworth et al. (1982), formally defined the Raven Gill Formation for the basaltic pillow lavas, basic sheets, brown mudstones and radiolarian cherts at the eponymous type locality (JF 176, Fig 3, Table 1). Floyd (1996, p. 157) noted the Arenig age of the conodonts from the type section in Raven Gill (Oepikodus evae Biozone - see also Lamont and Lindström 1957; Löfgren 1978, p. 38; Armstrong et al. 1990) but expressed uncertainty as to the unequivocal recognition of the Raven Gill Formation elsewhere along the LIZ. In addition to conodonts, radiolaria belonging to the family Inaniguttidae, spumellarian radiolaria and megascleres of hexactinellid sponges have been described from the Raven Gill Formation, but have limited biostratigraphical utility at present (Danelian and Floyd 
2001). Brown mudstones interbedded with radiolarian cherts in the type section contain acrotretid brachiopods assigned to the genus Paterula by Lamont and Lindström (1957). Floyd (1996) further designated the red and green siliceous mudstones described by Hepworth (1981) in Glencaple Burn, near to its confluence with Raven Gill [NS 9252 1988], as a reference section in the type area. Other reference sections were designated further to the northeast.

The rocks of the Raven Gill Formation are also exposed on the hills to the north of Crawford (see Leggett and Casey 1982, fig. 5) where faulted repetitions of grey radiolarian chert, greywacke and pillow lavas, brown shales and red cherty mudstones occur. The latter unit of red mudstones (localities JF 166, 175, Fig 3, Table 1,), now named the Castle Hill Member (Floyd 2001) has yielded conodonts of the O. evae Biozone (Armstrong and Dean 1996) and poorly preserved radiolaria (Danelian and Clarkson 1998; Danelian et al. 1999; Danelian and Floyd 2001). Danelian et al. (1999) and Danelian and Floyd (2001) also described the distinctive sponge Konyrium varium Nazarov and Popov 1976 from a loose block of red chert in the Southwood Burn (BGS locality JF 267, [NS 9400 2293]) in the Crawford area. This species has also been recorded in North America (Bergström 1979), and its type horizon in Kazakhstan is late Llanvirn in age (Nazarov and Popov 1976), suggesting that this block was derived from the Kirkton Formation (see also Armstrong \& Owen 2001).

\section{Kirkton Formation}

Hepworth (1981) proposed the 'Kirkton Beds' for the red, green and grey cherts and mudstones presumed to lie between the Raven Gill Formation and the Moffat Shale Group, along the LIZ. Floyd (1996) formalised the Kirkton Formation 
and proposed the temporary exposure in the 1976 gas pipeline trench at Abington as the type section. In the type section approximately $70 \mathrm{~m}$ of chert and siliceous mudstones overlie a lava succession up to 50m thick (Floyd 1996, p. 157). Reference sections in Glencaple Burn [NS 9252 1988; Hepworth 1981] within the type area, Normangill Burn [NS 971 241] and Hawkwood Burn [NS 976 254] were also defined. Lamont and Lindström (1957) described Pygodus anserinus from red chert sequences in Normangill Burn [NS 971 241], at Fardingmullach [NS 819 042] and also 11 km NW of Thornhill (see also Bergström and Orchard 1985, Armstrong et al. 1990 and Armstrong et al. 1996 for more recent identifications). Armstrong et al. (1990) described a conodont faunule from Hawkwood Burn, ascribing a Llanvirn age, though largely on negative evidence. The present study obtained anserinus Biozone conodont faunas from 12 localities in the Leadhills-Abington area. Their locations and conodont faunas are listed in Table 2.

Conodonts were first recorded from the Southern Uplands by Smith (1907) who reported conodonts in red siliceous mudstones of the Kirkton Formation at Morroch Bay [NX 017 524]. Subsequently, Lamont and Lindström (1957) described what would now be called Spinodus spinatus and Periodon aculeatus from red shales at the base of the succession. Lindström (1957) described coniform conodonts and Periodon (probably P. grandis see Löfgren 1978, p. 75) from black shales (Moffat Shale Group) with Climacograptus wilsoni Biozone graptolites (see also Bergström and Orchard 1985).

Graptolites of the gracilis Biozone are commonly found in the Glenkiln Shale Formation overlying or tectonically interleaved with the Kirkton Formation (Finney and Bergström 1986; Floyd 1996; Floyd 2001). The close association of anserinus Biozone conodonts and gracilis Biozone graptolites indicates a Llandeilian - 
Aurelucian age for the Kirkton Formation in the type area. In the more southerly exposures in Morroch Bay, the red shales and mudstones could also be of this age.

Conodont species within the Kirkton Formation are representative of the Protopanderodus-Periodon Biofacies indicating a deep water continental margin setting (Armstrong 1990). The new collections add little additional biostratigraphical information though we record $P$. anserinus in samples from Hunt Law Cleugh (JF177) which were previously thought to be Arenig in age (Danelian et al. 1999).

\section{Conodont specimens and curation}

In the Leadhills area, conodonts occur commonly as fragments and occasionally as demineralised moulds scattered on the bedding planes of red siliceous mudstones. Where original phosphate is preserved, the conodonts are black in colour, yielding a conodont colour alteration index (CAI) value of five, indicating heating to temperature in excess of $300^{\circ} \mathrm{C}$ (Epstein et al. 1977). White specimens could have a CAI value of 6 or higher indicating heating in excess of $480^{\circ} \mathrm{C}$, but are more likely altered to clay minerals. The nature of the preservation is such that it is difficult to give specific names to many specimens, which can therefore only be compared to named species or tentatively identified at best. Species lists for the new localities are provided in Tables 1 and 2. Comprehensive faunal lists for samples from each locality are presented in Armstrong et al. (2001) and biostratigraphically useful taxa are illustrated in Figures 4 - 8. Sample numbers are for rock fragments bearing the conodont specimens, each locality can thus have multiple sample numbers. All material is housed in the collections of the British Geological Survey, Edinburgh. 


\section{Conodont biostratigraphy of the Raven Gill Formation}

In the Ordovician, two conodont realms have traditionally been distinguished, the temperate to cool water North Atlantic Realm (NAR) and the tropical, warm water Midcontinent Realm (MR). The NAR has been reported from Balto-Scandinavia, the Appalachians, South China, South America, the Nevada-Utah region of North America, and northwestern Australia (Bergström 1990; Bagnoli and Stouge 1991), the MR from cratonic North America, North China, eastern Australia and the Siberian Platform (see Ji and Barnes 1994 for a review). Provincial faunas can be delimited within the two major realms (Bergström and Sweet 1966; Lindström 1971; Bergström 1971, 1973; Sweet and Bergström 1972; Barnes and Poplawski 1973): the Midcontinent Realm included the Midcontinent and Chinese provinces; the North Atlantic Realm included the Baltic and Precordillera provinces. In addition to these, Bagnoli and Stouge (1991) further differentiated a "Pandemic Group” of conodonts including Oepikodus and Periodon that preferred cool temperate oceanic water, representing a group of cosmopolitan species. The "Pandemic Group” appeared on the East European Platform during the Oepikodus evae transgression in the early Arenig (Stouge and Bagnoli 1988; Nielsen 1992). Raven Gill Formation conodonts are referred to the "Pandemic Group” of the North Atlantic Realm and compared for biostratigraphical purposes with Lower Ordovician sections from Balto-Scandinavia. Interestingly however, the fauna also contains Bergstroemognathus extensus, found in the Lower Ordovician of New York State but absent from Balto-Scandinavia itself (see below).

Rasmussen and Stouge (1995) recognised four conodont biofacies in the Arenig-Llanvirn Stein Formation, Norway. From shallow to deep water these were: 
Armstrong et al.

Draft 9, 6233 words

the Scalpellodus-Microzarkodina Biofacies, the Baltoniodus Biofacies, the

Drepanoistodus Biofacies and the Protopanderodus-Periodon Biofacies. Bagnoli and Stouge (1996) proposed an additional Oepikodus Biofacies, defined by the dominance of O. evae and subordinate Periodon, Drepanoistodus, Protopanderodus and Oistodus. They considered this to be a deep-water assemblage typical of slope deposits on palaeocontinental margins (Stouge and Bagnoli 1990). The fauna from the Raven Gill Formation is referred to the Oepikodus Biofacies.

Oepikodus evae Biozone fauna

The Raven Gill fauna is dominated by two species - Oepikodus evae (Lindström), the eponymous zonal species, and Periodon flabellum (Lindström), with subsidiary numbers of Drepanoistodus forceps (Lindström), Drepanodus arcuatus Pander, Oistodus lanceolatus Pander, Paroistodus originalis (Sergeeva), Paroistodus parallelus (Pander), Paroistodus proteus (Lindström), Protopanderodus rectus (Lindström) and Paracordylodus gracilis Lindström. All these species are typical of the O. evae Biozone in Balto-Scandinavia (Lindström 1960, 1971; van Wamel 1974; Stouge and Bagnoli 1988; Bagnoli and Stouge 1991, 1997; Löfgren 1978, 1993, 1994). In addition, the fauna contains two specimens tentatively assigned to Bergstroemognathus extensus Serpagli, a species absent from Balto-Scandinavia but found in coeval strata in New York State (Landing 1976).

In Balto-Scandinavia, O. evae and P. flabellum first appear in the evae Biozone (Löfgren 1978). Löfgren $(1993,1994)$ modified the original biozonation proposed by Lindström (1971) for the region, informally subdividing the evae Biozone into four sub-biozones. The lower evae Sub-biozone contains O. evae and reworked and in situ Prioniodus elegans (Löfgren 1978, 1993, 1994; Bergström 1988; Bagnoli and Stouge 1997). The lower-middle and middle-upper evae sub-biozones have the highest 
Armstrong et al.

Draft 9, 6233 words

diversity of taxa including the zonal index species. O. evae disappears in the upper evae Sub-biozone, leaving an impoverished coniform fauna including species of Protopanderodus, Drepanoistodus and Paroistodus (Kohut 1972; Löfgren 1978, 1993, 1994; Bagnoli and Stouge 1997).

The evae Biozone has also been reported from cratonic margin sections in North America. Landing (1976) described a fauna from the Deep Kill Shale in New York State including the zonal index species, P. flabellum, Scolopodus rex, Paroistodus? gladiatus, Paracordylodus gracilis, Paroistodus originalis and questionably P. parallelus, Protopanderodus gradatus (which appears to replace $P$. rectus in the North American faunas) and Bergstroemognathus cf. extensus. Drepanoistodus forceps and Oistodus lanceolatus are present in Balto-Scandinavia and Scotland but absent from the Deep Kill Shale. Bergström and Cooper (1973) described an evae Biozone fauna from the Upper Member of the Marathon Limestone, Texas, which contained O. evae, Paroistodus parallelus and Protopanderodus rectus. The evae Biozone in Argentina (Serpagli 1974) appears similar to that from the Deep Kill Shale and Löfgren (1978) compared this directly to the evae Biozone in Balto-Scandinavia.

The conodont fauna from the Raven Gill Formation therefore contains taxa typical of the O. evae Biozone, possibly the lower -middle and middle-upper subbiozones, indicative of a lower Whitlandian, Arenig age (sensu Fortey et al. 1995). Samples from Glencaple Burn (JF175, 175A, 175B), contain an impoverished coniform fauna and lack the zonal index species. These samples could conceivably be from the upper part of the evae Biozone, but still within the lower Whitlandian.

In Britain, the O. evae Biozone is recorded only from the Raven Gill Formation in the Northern Belt of the Southern Uplands in Scotland (Bergström \& Orchard 
1985). However, conodonts of an equivalent age have been reported from the

Dounans Limestone, Highland Border Complex (Ethington and Austin 1991). This fauna may have occupied a shelf-margin setting and includes representatives of both the North Atlantic and American Midcontinent realms. The presence of Periodon flabellum indicates that the Dounans Limestone can be correlated with the interval of the Ross/Hintze zone J through lower zone L, approximately equivalent to the O. evae and B. triangularis conodont biozones of the North Atlantic Realm (Ethington and Austin 1991).

Palaeogeographical reconstructions (Torsvik et al. 1996) indicate that the Highland Border and contiguous terranes to the south lay adjacent to Laurentia within tropical latitudes. Although there was significant tectonic re-organisation within the paratectonic Caledonides during the Grampian and subsequent Caledonian deformations, it is reasonable to consider that the conodont fauna of the Raven Gill Formation represents a deep-water slope environment, and is partly equivalent to that of the Dounans Limestone.

\section{Implications}

The expanded conodont biostratigraphical dataset supports the presence of a major stratigraphical gap within the Crawford Group, the oldest part of the Northern Belt succession. Cherts and volcanic rocks occur at two distinct stratigraphical levels, in the Raven Gill Formation of Whitlandian, low to mid-Arenig age and the LlandeilianAurelucian, late Llanvirn to early Caradoc Kirkton Formation. The stratigraphical gap is thus equivalent to the upper Arenig to upper Llanvirn (Llandeilian), a period of approximately 10 million years (Fortey et al. 2000). 
The existence of a large stratigraphical gap within the Crawford Group is inconsistent with the accretionary prism model for the Southern Uplands as this assumes continual accretion of Layer 1 sediments from the Arenig to Silurian (Leggett et al. 1979). Alternatively, Armstrong and Owen (2001) suggested that the Raven Gill Formation was part of a pre-Grampian ocean margin succession of Novantia, an Ordovician arc terrane now concealed beneath the Southern Uplands Allochthon and that the Raven Gill Formation was tectonically emplaced during the formation of the Southern Uplands (see also Leggett et al. 1979). This hypothesis is consistent with the Raven Gill Formation cherts having a continental margin Rare Earth Element geochemistry (Armstrong et al. 1999) and the presence of an Oepikodus evae Biofacies conodont assemblage.

The new mapping indicates that the Raven Gill Formation is restricted to geographically isolated and probably fault-controlled outcrops in the type area. A possible interpretation of these outcrop patterns is that the exposures of the Raven Gill Formation represent olistoliths in a mélange within the lower Crawford Group. This reinterpretation implies that the Raven Gill Formation was exposed along the margin to the Northern Belt Basin in the early Middle Ordovician, albeit in a deep water setting.

The Kirkton Formation (and coeval Currarie Formation in the Ballantrae area) crops out in several tracts of the Northern Belt and clearly forms part of an extensive basal unit to the succeeding and prograding greywacke succession. Continental margin REE patterns for cherts within the Kirkton Formation (Owen et al. 1999) and the presence of conodonts of the Protopanderodus-Periodon Biofacies, indicate that the Northern Belt Basin succession was initiated in the latest Llanvirn, in a deepwater continental margin setting (Owen et al. 1999). 


\section{Conclusions}

Samples from the Raven Gill Formation, within the LIZ, contain conodonts of the Oepikodus evae Biozone and are of lower Whitlandian, Arenig age (sensu Fortey et al. 1995). The Raven Gill Formation is reinterpreted as a mélange of late Llanvirn to early Caradoc age, within the lower Crawford Group. The Kirkton Formation, though lithologically similar, can be distinguished on the widespread presence of Llandeilian - Aurelucian, P. anserinus Biozone conodonts, and forms the basal unit of the Northern Belt Basin succession. Despite extensive recollecting, no conodonts representing the intervening upper Arenig and Llanvirn have been found. It is concluded, therefore, that there is a significant stratigraphical gap within the Crawford Group.

The chert-bearing succession of the Northern Belt of the Southern Uplands represents the juxtaposed sedimentary records of two entirely separate basins. The older pre-dates the Grampian assembly of the Laurentian margin while the younger Northern Belt Basin sensu stricto entirely post-dates this event. A stratigraphical gap of some 10 million years within the Crawford Group is incompatible with the model of progressive accretion of Layer 1 sediments to the leading edge of Laurentia, during the development of an accretionary prism over this period.

Acknowledgements. This work was conducted with funding from a BGS-University Collaboration grant GA/98E/46. Dr A. W. Owen, Prof. B. J. Bluck and Prof. E. N. K. Clarkson are thanked for detailed discussions on Southern Uplands geology and Caledonian tectonics. Dr P. Stone and M. Dean are thanked for improvements to an 
earlier version of this paper. This paper is published with the permission of the Director, British Geological Survey (NERC).

\section{Appendix - Systematic notes}

Taxa from the Kirkton Formation are well known and have been recently described by Armstrong (1997, 2000). Taxa from the Raven Gill Formation have not been formally described. The nature of the preservation of this collection makes it difficult to contribute to the systematic palaeontology of the species recorded. Consequently Oepikodus evae Biozone species are listed below with authorisation and the most recent citation with which the authors agree. The O. evae Bizone fauna is dominated by prioniodinid and coniform species for which natural assemblages are not known. Rigorous hypotheses of topological homology cannot be easily inferred from secondary morphological criteria, and notational schemes proposed by Sweet (1988) and Sansom et al. (1994) are retained, indicating no firm topological homology (Purnell et al. 2000, p. 119). Specimens were photographed using a Wild photomicroscope and FP4 monochrome film.

Bergstroemognathus extensus (Graves and Ellison, 1941). Figure 8i. Barnes et al., 1991, pl.1, figs 28-30. Only two S elements have been discovered. Drepanodus arcuatus Pander, 1856. Figure 4g, i. Zhang, 1998, p. 59-60, pl.4, figs 7$11,15-16$.

Drepanoistodus forceps (Lindström, 1955). Figure 4a, b. Löfgren, 1996, text-figs 5:A-C. 
Oepikodus evae (Lindström,1955). Figure 5a-j. Löfgren, 1996, text-figs 5:A-F. The distinction of $\mathrm{P}$ and S elements is difficult in our collection. S elements tend to have longer processes.

Oistodus lanceolatus Pander,1856. Figure 4e. Bergström, 1988, pl. 2, figs 17-19.

Paracordylodus gracilis Lindström, 1955. Figure 6b, c, e, f. Stouge and Bagnoli, 1988, pp.125-126, pl. 8, figs 16-19. S elements in this collection have a costa on each denticle of the posterior process.

Paroistodus originalis (Sergeeva, 1963). Figure 4c, h. Löfgren, 1996, text-figs 5:P-Q. Paroistodus parallelus (Pander,1856). Figure 7a. Löfgren, 1996, text-figs 5:S-T. The species has a variably developed carina on the cusp.

Periodon flabellum (Lindström, 1955). Figure 6a, h-k. Löfgren, 1996, pp.174-175, text-figs 5:AK-AL. In our collection, S elements are significantly more abundant than P elements.

Protopanderodus varicostatus (Sweet \& Bergström, 1962). Figure 4d. Figures $4 \mathrm{j}$ and $4 \mathrm{k}$ are only tentatively assigned to this species due to poor preservation. Protopanderodus rectus (Lindström, 1955). Figure 4f. Stouge and Bagnoli, 1990, p.23, pl. 8, figs $1-5$. 


\section{References}

ARMSTRONG, H. A. 1990. Conodonts from the Lower Silurian of the north Greenland carbonate platform. Bulletin Groenlands Geologiske Undersogelse, 159, 151pp.

ARMSTRONG, H. A. 1997. Conodonts from the Shinnel Formation, Tweeddale Member (middle Ordovician), Southern Uplands, Scotland. Palaeontology, 40, 763-99.

ARMSTRONG, H. A. 2000. Conodont micropalaeontology of mid-Ordovician aged limestone clasts from LORS conglomerates, Lanark and Strathmore basins, Midland Valley, Scotland. Journal of Micropalaeontology, 19, 45-59.

ARMSTRONG, H. A., CLARKSON, E.N.K. \& OWEN, A. W. 1990. A new Lower Ordovician conodont faunule from the Northern Belt of the Southern Uplands of Scotland. Scottish Journal Geology, 26, 47-52.

ARMSTRONG, H. A. \& DEAN, M. T. 1996. Conodonts from Ruddenleys, Lamancha and Crawford, Southern Uplands, Scotland. British Geological Survey Technical Report WH/96/192R.

ARMSTRONG, H. A., FLOYD, J. D. \& BARRON, H. F. 2001. Conodont biostratigraphy of the Crawford Group, Southern Uplands. British Geological Survey Research Report RR/01/05

ARMSTRONG, H. A. \& OWEN, A. W. 2001. Terrane evolution of the paratectonic Caledonides of northern Britain. Journal of the Geological Society, London, 158, 475-86.

ARMSTRONG, H. A., OWEN, A. W., SCRUTTON, C. T., CLARKSON, E. N. K. \& TAYLOR, C. 1996. Evolution of the Northern Belt, Southern Uplands - 
implications for the Southern Uplands controversy. Journal of the Geological Society, London, 153, 197-205.

ARMSTRONG, H. A., OWEN, A.W. \& FLOYD, J. D. 1999. Rare Earth Element geochemistry of Arenig cherts from the Ballantrae Ophiolite and Leadhills Imbricate Zone, Southern Scotland - implications for origin and significance to the Caledonian Orogeny. Journal of the Geological Society, London, 156, $549-60$.

BAGNOLI, G. \& STOUGE, S. 1991. Paleogeographic distribution of Arenig (Lower Ordovician) conodonts. Annual Academia Brasil, 63, 171-83.

BAGNOLI, G. \& STOUGE, S. 1996. Changes in conodont provincialism and biofacies during the lower Ordovician in Öland, Sweden. Palaeopelagos, 6, 19-29.

BAGNOLI, G. \& STOUGE, S. 1997. Lower Ordovician (Billingenian-Kunda) conodont zonation and provinces based on sections from Horns Udde, north Öland, Sweden. Bullettino della Società Paleontologica Italiana, 35, 109-63.

BARNES, C. R., JI, Z. \& POHLER, S. M. L. 1991. A review of Ordovician conodont paleontology of the Canadian Cordillera. Geological Survey of Canada Bulletin No. 417, 27-39.

BARNES, C. R., \& POPLAWSKI, M. L. S. 1973. Lower and Middle Ordovician conodonts from the Mystic Formation, Quebec, Canada. Journal of Paleontology, 50, 205-17.

BERGSTRÖM, S. M. 1971. Conodont biostratigraphy of the Middle and Upper Ordovician of Europe and eastern North America. Geological Society of America Memoir, 127, 83-157. 
BERGSTRÖM, S. M. 1973. Biostratigraphy and facies relations in the lower Middle Ordovician of easternmost Tennessee. American Journal of Science, 273-A, 261-93.

BERGSTRÖM, S. M. 1979. First report of the enigmatic Ordovician microfossil Konyrium in North America. Journal of Palaeontology, 53, 320-27.

BERGSTRÖM, S. M. 1988. On Pander's Ordovician conodonts: distribution and significance of the Prioniodus elegans fauna in Baltoscandia. Lethaea, 59, 21751.

BERGSTRÖM, S. M. 1990. Biostratigraphic significance of Middle and Upper Ordovician conodonts in the Girvan succession, south-west Scotland. Courier Forschungsinstitut Senckenberg, 118, 1-43.

BERGSTRÖM, S. M. \& COOPER, R. A. 1973. Didymograptus bifidus and the transAtlantic correlation of the Lower Ordovician. Lethaea, 6, 313-40.

BERGSTRÖM, S. M. \& ORCHARD, M.J. 1985. Conodonts of the Cambrian and Ordovician Systems from the British Isles. In, HIGGINS, A.C. \& AUSTIN, R.L. (eds) A stratigraphical index of conodonts. Ellis Horwood, Chichester, 32-67.

BERGSTRÖM, S. M. \& SWEET, W.C. 1966. Conodonts from the Lexington Limestone (Middle Ordovician) of Kentucky and its lateral equivalents in Ohio and Indiana. Bulletin of American Paleontology, 50, 271-441.

DANELIAN, T. 1999. Taxonomic study of Ordovician (Llanvirn-Caradoc) Radiolaria from the Southern Uplands (Scotland, UK). Geodiversitas, 21, 62535.

DANELIAN, T. \& CLARKSON, E. N. K. 1998. Ordovician radiolaria from bedded cherts of the Southern Uplands. Scottish Journal of Geology, 34, 133-7. 
DANELIAN, T. \& FLOYD, J. D. 2001. Progress in describing Ordovician siliceous biodiversity from the Southern Uplands (Scotland, U.K.). Transactions of the Royal Society of Edinburgh: Earth Sciences, 91, 489-498.

DANELIAN, T., FLOYD, J. D. \& ARMSTRONG, H. A. 1999. Radiolarian and conodont biostratigraphy of Arenig-Llanvirn chert sequences in the Southern Uplands of Scotland. British Geological Survey Technical Report WA/99/65. EPSTEIN, A. G., EPSTEIN, J. B. \& HARRIS, L. 1977. Conodont color alteration an index to organic metamorphism. U. S. Geological Survey Professional Paper 995, 1-27.

ETHINGTON, R. L. \& AUSTIN, R. L.1991. Conodonts of the Dounans Limestone, Highland Border Complex, Scotland. Journal of Micropalaeontology, 10, 5156.

FINNEY, S. C. \& BERGSTRÖM, S. M. 1986. Biostratigraphy of the Ordovician Nemagraptus gracilis Zone. In, HUGHES, C. P. \& RICKARDS, R. B. (eds.) Palaeoecology and biostratigraphy of graptolites. Geological Society, London Special Publication, 20, 47-59.

FLOYD, J. D. 1996. Lithostratigraphy of the Ordovician rocks in the Southern Uplands: Crawford Group, Moffat Shale Group, Leadhills Supergroup. Transactions of the Royal Society of Edinburgh: Earth Sciences, 86, 153-65. FLOYD, J. D. 2001. The Southern Uplands Terrane: a stratigraphical review. Transactions of the Royal Society of Edinburgh: Earth Sciences, 91, 349-62. FORTEY, R. A., HARPER, D. A. T., INGHAM, J. K., OWEN, A. W. \& RUSHTON, A. W. A. 1995. A revision of the Ordovician Series and Stages in the historical type area. Geological Magazine, 132, 15-30. 
FORTEY, R. A., HARPER, D. A. T., INGHAM, J. K., OWEN, A. W., PARKES, M. A., RUSHTON, W. A. \& WOODCOCK, N. H. 2000. A revised correlation of Ordovician rocks in the British Isles. Geological Society, London, Special Report No. 24.

HEPWORTH, B. C. 1981. Geology of the rocks between Leadhills and Abington, Lanarkshire. Unpubl. Ph.D. thesis. University of St Andrews.

HEPWORTH, B. C., OLIVER, G. J. H. \& MCMURTRY, M. J. 1982. Sedimentology, volcanism, structure and metamorphism of a Lower Palaeozoic accretionary complex; Bail Hill-Abington area of the Southern Uplands of Scotland. In LEGGETT, J. K. (ed.) Trench-forearc Geology: Sedimentation and Tectonics on Modern and Ancient Active Plate Margins. Geological Society, London, Special Publication, 10, 521-33.

HUTTON, D. H. W.\& MURPHY, F. C. 1987. The Silurian of the Southern Uplands and Ireland as a successor basin to the end-Ordovician closure of the Iapetus. Journal of the Geological Society, London, 144, 765-72.

JI, Z. \& BARNES, C. R. 1994. Lower Ordovician conodonts of the St. George Group, Port au Port Peninsula, western Newfoundland, Canada. Palaeontographica Canadiana, 11, 149pp.

KOHUT, J. J. 1972. Conodont biostratigraphy of the Lower Ordovician Orthoceras and Stein Limestones (3c), Norway. Norsk Geologisk Tidsskrift, 52, 427-55.

LAMONT, A. \& LINDSTRÖM, M. 1957. Arenigian and Llandeilian cherts identified in the Southern Uplands of Scotland by means of conodonts, etc. Transactions of the Edinburgh Geological Society, 17, 60-70. 
LANDING, E. 1976. Early Ordovician (Arenigian) conodont and graptolite biostratigraphy of the taconic allochthon, eastern New York. Journal of Paleontology, 50, 614-46.

LEGGETT, J. K. 1978. Studies in the Ordovician rocks of the Southern Uplands, with particular reference to the Northern Belt. Unpublished D.Phil. thesis. University of Oxford.

LEGGETT, J. K. \& CASEY, D. M. 1982. The Southern Uplands Accretionary Prism: implications for controls on structural development of subduction complexes. In DRAKE, C. L. \& WATKINS, J. S. (eds) Continental Margin Processes. American Association of Petroleum Geologists, 24, 377-93.

LEGGETT, J. K., McKERROW, W.S. \& EALES, M. H. 1979. The Southern Uplands of Scotland: A Lower Palaeozoic accretionary prism. Journal of the Geological Society, London, 136, 755-70.

LINDSTRÖM, M. 1957. Two conodont faunas found with zonal graptolites.

Geologiska Föreningens i Stockholm, Förhandlingar, 79, 161-78.

LINDSTRÖM, M. 1960. A Lower-Middle Ordovician succession of conodont faunas. $21^{\text {st }}$ International Geological Congress Reports, 7, 88-96.

LINDSTRÖM, M. 1971. Lower Ordovician conodonts of Europe. Bulletin of the Geological Society of America, 127, 21-61.

LÖFGREN, A. 1978. Arenigian and Llanvirian conodonts from Jämtland, northern Sweden. Fossils and Strata, 13, 1-129.

LÖFGREN, A. 1993. Arenig conodont successions from central Sweden. Geologiska Föreningens i Stockholm, Förhandlingar, 115, 193-207.

LÖFGREN, A. 1994. Arenig (Lower Ordovician) conodonts and biozonation in the eastern Siljan District, central Sweden. Journal of Paleontology, 68, 1350-68. 
LÖFGREN, A. 1996. Lower Ordovician conodonts, reworking, and biostratigraphy of Orreholmen quarry, Västergötland, south-central Sweden. Geologiska Föreningens i Stockholm, Förhandlingar, 118, 169-83.

MCKERROW, W. S., LEGGETT, J. K. \& EALES, M. H. 1977. Imbricate thrust model of the Southern Uplands of Scotland. Nature, 267, 237-9.

MORRIS, J. H. 1987. The Northern Belt of the Longford-Down, Ireland and Southern Uplands, Scotland: an Ordovician back-arc basin. Journal of the Geological Society, London, 144, 773-86.

NAZAROV, B. B. \& POPOV, L. E. 1976. Radiolarians, inarticulate brachiopods and organisms of uncertain systematic position from the Middle Ordovician of Eastern Kazakhstan. Palaeontological Journal, 4, 33-42.

NIELSEN, A. T. 1992. International correlation of the Arenigian (Early Ordovician) based on sequence and ecostratigraphy. In WEBBY, B. D. \& LAURIE J. R. (eds), Global perspectives on Ordovician Geology, 367-380.

OWEN, A. W., ARMSTRONG, H. A. \& FLOYD, J. D. 1999. Rare Earth Element geochemistry of upper Ordovician cherts from the Southern Uplands fingerprinting formations and elucidating environments of deposition. Journal of the Geological Society. London, 156, 191-204.

PURNELL, M. A. P., DONOGHUE, P. C. J. \& ALDRIDGE, R. J. 2000. Orientation and anatomical notation in conodonts. Journal of Paleontology, 74, 113-122.

RASMUSSEN, J. A. \& STOUGE, S. 1995. Late Arenig-Early Llanvirn conodont biofacies across the Iapetus Ocean. In COOPER, J. D., DROSER, M. L. \& FINNEY, S. C. (eds) - Ordovician Odyssey, Pacific Section, SEPM, 443-47.

SANSOM, I., ARMSTRONG, H. A. \& SMITH, M. P. 1994. The apparatus architecture of panderodontid euconodonts. Palaeontology, 37, 781-801. 
SERPAGLI, E. 1974. Lower Ordovician conodonts from Precordilleran Argentina (Province San Juan). Bullettino della Società Paleontologica Italiana, 13, 1798.

SMITH, J. 1907. On the occurrence of conodonts in the Arenig-Llandeilo formations of the Southern Uplands. Transactions of the Natural History Society of Glasgow, 7, 235-52.

SMITH, R. A., PHILLIPS, E. R., FLOYD, J. D., BARON, H. F. \&PICKETT, E. A. 2001. The Northern Belt 100 years on: a revised model of the Ordovician tracts near Leadhills, Scotland. Transactions of the Royal Society of Edinburgh: Earth Sciences, 91, 421-434 (for 2000).

STONE, P., FLOYD, J. D., BARNES, R. P. \& LINTERN, B. C. 1987. A sequential back-arc basin and foreland basin thrust duplex model for the Southern Uplands of Scotland. Journal of the Geological Society, London, 144, 753-64. STOUGE, S. \& BAGNOLI, G. 1988. Early Ordovician conodonts from the Cow Head Peninsula, western Newfoundland. Paleontographia Italica, 75, 89-179. STOUGE, S. \& BAGNOLI, G. 1990. Lower Ordovician (Volkhovian-Kundan) conodonts from Hagudden, northern Öland, Sweden. Paleontographia Italica, 77, 54pp.

SWEET, W. C. 1988. The Conodonta. Morphology, Taxonomy, Paleoecology, and Evolutionary History of a Long-Extinct Animal Phylum. Oxford Monographs on Geology and Geophysics, No. 10. Clarendon Press, Oxford.

SWEET, W. C. \& BERGSTRÖM, S. M. 1972. Multielement taxonomy and Ordovician conodonts. Geologica et Palaeontologica, 1, 29-42.

TORSVICK, T. H., SMETHURST, M. A., MEERT, J. G., VAN DER VOO, R., McKERROW, W. S., BRASIER, M. D., STURT, B. A. \& WALDERHAUG, 
H. J. 1996. Continental break-up and collision the Neoproterozoic and

Palaeozoic - A tale of Baltica and Laurentia. Earth Science Reviews, 40, 229-

58.

VAN WAMEL, W. A. 1974. Conodont biostratigraphy of the Upper Cambrian and Lower Ordovician of North-Western Öland, southeastern Sweden. Utrecht Micropaleontolgical Bulletin, 10, 1-126.

ZHANG JIANHUAN, 1998. Conodonts from the Guniutan Formation (Llanvirnian) in Hubei and Hunan Provinces, south-central China. Acta universitatis Stockholmiensis, Stockholm Contributions in Geology, 46, 161. 


\section{Figure Captions}

Figure 1. Outline geology of the Leadhills - Crawford area in the Southern Uplands showing localities with Oepikodus evae Biozone faunas (white x) and those with Pygodus anserinus Biozone faunas (black +). Inset shows area of main map.

Geological units: KKF, Kirkcolm Formation; MCHB, Marchburn Formation; MFS, Moffat Shale Group and Crawford Group (undivided); PPF, Portpatrick Formation; SHIN, Shinnel Formation; LIZ, Leadhills Imbricate Zone.

Figure 2. Simplified stratigraphical diagram of early-mid Ordovician successions in the Southern Uplands, highlighting the established biozones recognised so far in the radiolarian cherts of the Crawford Group (after Danelian 1999). Lithostratigraphical terminology according to Floyd (1996, 2001). Chronostratigraphy and biostratigraphy from Fortey et al. (1995).

Figure 3. Outline stratigraphy at the three known exposures of Raven Gill Formation near Abington. Raven Gill (JF 176) is the type locality for the Raven Gill Formation; Castle Hill (JF 166) is the type locality for the Castle Hill Member (Floyd 1996, 2001).

Figure 4. a, b. Drepanoistodus forceps (Lindström, 1955). a, sample 17E111, x50. b, sample 17E111, 100 .

c, h. Paroistodus originalis (Sergeeva, 1963). c, sample 17E93, x50. h, sample 17E93, 100. 
d. Protopanderodus varicostatus (Sweet and Bergström, 1962). Sample 17E171, $\mathrm{x} 40$.

e. Oistodus lanceolatus Pander, 1856. Sample 16E952, x50.

f. Protopanderodus rectus (Lindström, 1955). Sample 16E778, x25.

g, i. Drepanodus arcuatus Pander, 1856. g, sample 16E774, x14. i, sample 16E773, x14.

j. Protopanderodus ?varicostatus (Sweet and Bergström, 1962), sample 17E110, x50.

k. Protopanderodus ?varicostatus (Sweet and Bergström, 1962), sample17E94, x50.

Figure 5. a-j. Oepikodus evae (Lindström, 1955). All specimens x50. a, 1, S element, sample 16E788. b, S element, sample 17E117. c, M element, sample 16E789. d, M element, sample 16E766. e, S element, sample 16E802. f, S element, 16E793. g, P element, sample 17E107. h, P element, sample 17E108. i, S element, sample 17E118. j, P element, sample 15E759.

Figure 6. a, h-k. Periodon flabellum (Lindström, 1955). All specimens x50. a, Pa element, sample 16E858. h, Pb element, sample 16E951. i, ?S element, sample 16E796. j, M element, sample 16E799. k, S element, sample $16 E 787$.

b, c, e, f. Paracordylodus gracilis (Lindström, 1955). All specimens x50. b, S element, sample 17E107. c, M element, sample 16E798. e, S element, sample 17E124. f, S element, sample 16E794.

d, g. Spinodus spinatus (Hadding, 1913). Both specimens x50. d, S element, sample 17E174. g, S element, sample 17E177. 
Figure 7. a. Paroistodus parallelus (Pander, 1856), sample 16E784, x45.

b, c, e-h. Periodon aculeatus (Hadding, 1913). All specimens x50. b, S element, sample 17E181. c, S element (mould), sample 17E267. e, Sc element (mould), sample 16E834. f, M element, sample 16E951. g, S element, sample 17E310. h, Pb element, sample 17E127.

d. Spinodus spinatus (Hadding, 1913), S element, sample 15E6586, x40.

Figure 8. a, d. Periodon aculeatus (Hadding, 1913). All specimens x50. a, S element, sample 17E272. d, S element, sample 17E309.

b, c, e, f, k. Pygodus anserinus Lamont and Lindström, 1957. All specimens x50. b, Pa element, sample 15E6592. c, Pa element, sample 15E6593. e, Pb element, sample 17E141. f, Pa element, sample 17E137. k, Pc element, sample 17E151.

h. Periodon flabellum (Lindström, 1955), S element, sample 17E108, x50.

g, j. Periodon aculeatus (Hadding, 1913). Both specimens x50. g, S element, sample 16E863. j, Pb element, sample 16E851.

i. Bergstroemognathus extensus (Graves and Ellison, 1941), P element, sample 16E862, x50. 


\begin{tabular}{|c|c|c|c|c|c|c|c|c|c|c|c|c|c|c|c|c|c|c|}
\hline $\begin{array}{l}\text { BGS } \\
\text { locality }\end{array}$ & $\begin{array}{l}\text { Grid } \\
\text { Reference } \\
\text { [NS] }\end{array}$ & Locality & $\begin{array}{l}\frac{0}{0} \\
\frac{\sigma}{0} \\
\frac{0}{0} \\
\frac{0}{d} \\
\text { n. }\end{array}$ & 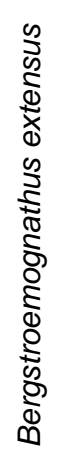 & 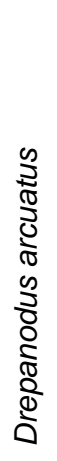 & 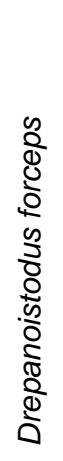 & 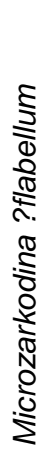 & 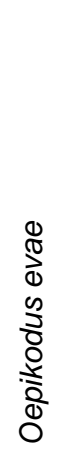 & 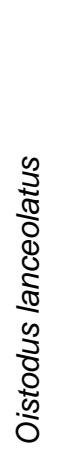 & 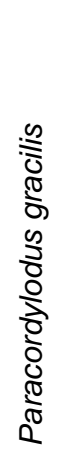 & 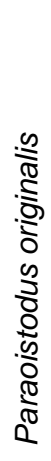 & 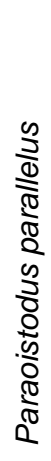 & $\begin{array}{l}0 \\
0 \\
0 \\
\frac{0}{0} \\
0 \\
\frac{0}{0} \\
0 \\
\frac{0}{2} \\
\frac{\pi}{\pi} \\
0\end{array}$ & 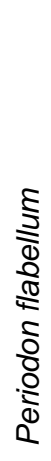 & 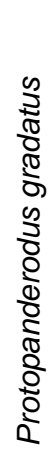 & 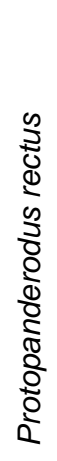 & 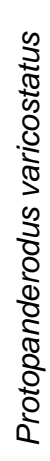 & 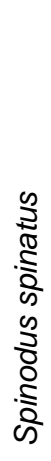 \\
\hline $\begin{array}{l}\text { JF176 } \\
\text { JF176A } \\
\text { JF176B } \\
\text { JF176C } \\
\end{array}$ & $\begin{array}{l}92041989 \\
92041989 \\
92041989 \\
92041989 \\
\end{array}$ & $\begin{array}{l}\text { Raven Gill, north branch } \\
\text { Raven Gill, NW side of gully } \\
\text { Raven Gill, NE side of gully } \\
\text { Raven Gill, SE side of gully }\end{array}$ & & $?$ & $x$ & cf & & $\begin{array}{l}x \\
x \\
x\end{array}$ & & $\begin{array}{l}\mathrm{x} \\
\mathrm{x} \\
\mathrm{x} \\
\end{array}$ & $x$ & $x$ & & $\begin{array}{l}\mathrm{cf} \\
\mathrm{x} \\
\mathrm{x}\end{array}$ & $x$ & $\mathrm{x}$ & $x$ & \\
\hline $\begin{array}{l}\text { JF175 } \\
\text { JF175A } \\
\text { JF175B }\end{array}$ & $\begin{array}{l}92551989 \\
92551989 \\
92551989 \\
\end{array}$ & $\begin{array}{l}\text { Glencaple Burn, Abington } \\
\text { Glencaple Burn 'A', Abington } \\
\text { Glencaple Burn 'B', Abington }\end{array}$ & $x$ & ? & & & $x$ & ? & $\mathrm{x}$ & $\begin{array}{l}? \\
\times\end{array}$ & $\mathrm{x}$ & & $x$ & $\begin{array}{l}? \\
\mathrm{x} \\
\mathrm{x}\end{array}$ & & & & ? \\
\hline JF166 & 93732175 & Castle Hill track, Crawford & & & & & & $\mathrm{x}$ & & $\mathrm{x}$ & $\mathrm{cf}$ & & & $\mathrm{x}$ & & & & \\
\hline
\end{tabular}

Table 1. Localities yielding Oepikodus evae Biozone faunas, and the distribution of species recorded. 



\begin{tabular}{|c|c|c|c|c|c|c|c|c|c|c|}
\hline $\begin{array}{l}\text { BGS } \\
\text { locality }\end{array}$ & $\begin{array}{l}\text { Grid } \\
\text { Reference } \\
\text { [NS] }\end{array}$ & Locality & 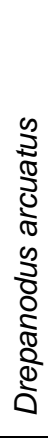 & 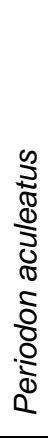 & 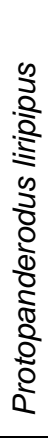 & 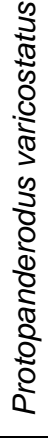 & 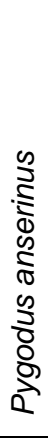 & 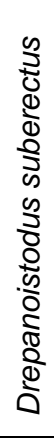 & 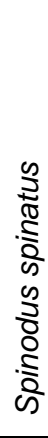 & 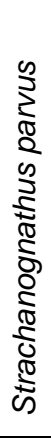 \\
\hline JF 177 & 87081568 & Hunt Law Cleugh, Snar Water & cf & $x$ & & $x$ & $x$ & $\mathrm{cf}$ & $?$ & \\
\hline JF233 & 87521606 & Glenkip Head, Leadhills & $?$ & $x$ & & & & $x$ & $x$ & \\
\hline $\begin{array}{l}\text { JF227A } \\
\text { JF227B } \\
\text { JF227C } \\
\text { JF227D } \\
\text { JF227E }\end{array}$ & $\begin{array}{l}88431652 \\
88431652 \\
88431652 \\
88431652 \\
88431652 \\
\end{array}$ & $\begin{array}{l}\text { Gripps Shaft, Leadhills } \\
\text { Gripps Shaft, Leadhills } \\
\text { Gripps Shaft, Leadhills } \\
\text { Gripps Shaft, Leadhills } \\
\text { Gripps Shaft, Leadhills }\end{array}$ & $x$ & $\begin{array}{l}x \\
x \\
x \\
x \\
x\end{array}$ & & $\begin{array}{l}x \\
x \\
x\end{array}$ & $\begin{array}{l}x \\
x \\
x\end{array}$ & $\begin{array}{l}\mathrm{cf} \\
\mathrm{x}\end{array}$ & $\begin{array}{l}x \\
x\end{array}$ & $x$ \\
\hline JF246B & 88291713 & Gripps Cleugh, Leadhills & & $x$ & & $x$ & $x$ & & & \\
\hline JF 262 & 89141845 & Clow Gill (lower), Leadhills & & $x$ & & & $x$ & & & \\
\hline JF260 & 89911815 & Clow Gill (upper), Leadhills & & $\mathrm{x}$ & & $x$ & $x$ & sp. & & \\
\hline JF257 & 91511961 & Kirk Gill Cleugh, Abington & & $\mathrm{x}$ & & & $x$ & & & \\
\hline JF258 & 91502070 & Kirk Gill, Abington & & $x$ & & & $x$ & & & \\
\hline HB339 & 97792460 & Black Grain, Abington & & $x$ & cf & $\mathrm{x}$ & $x$ & & & \\
\hline HB383 & 98502533 & Lead Burn, Abington & & $x$ & & & $x$ & & & \\
\hline HB384 & 98702516 & Lead Burn, Abington & & $x$ & & & $x$ & & $x$ & \\
\hline HB385 & 98582528 & Lead Burn, Abington & & & & & $x$ & & & \\
\hline
\end{tabular}

Table 2. Localities yielding Pygodus anserinus Biozone faunas, and the distribution of species recorded 


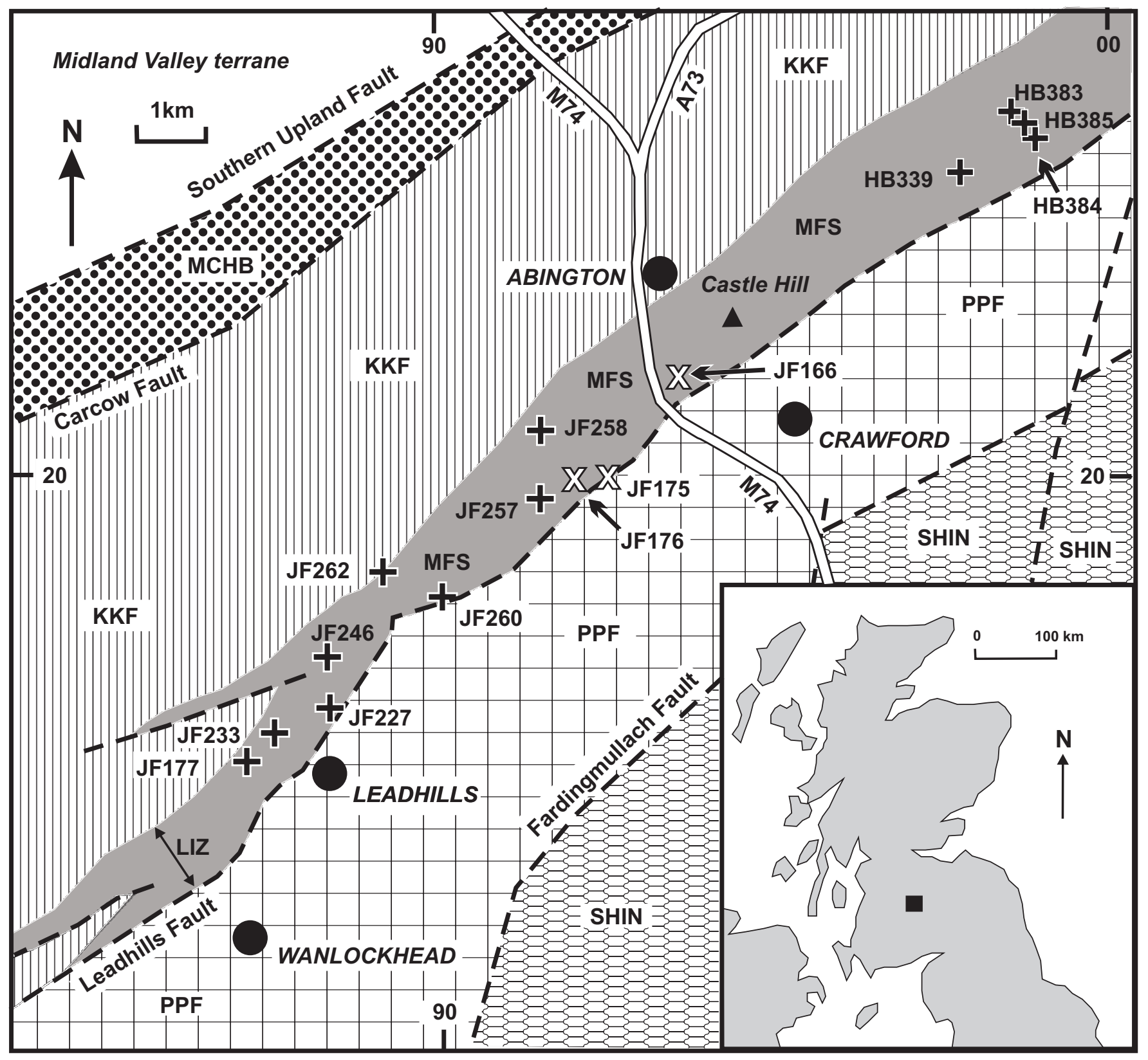

Armstrong et al. Figure 1 


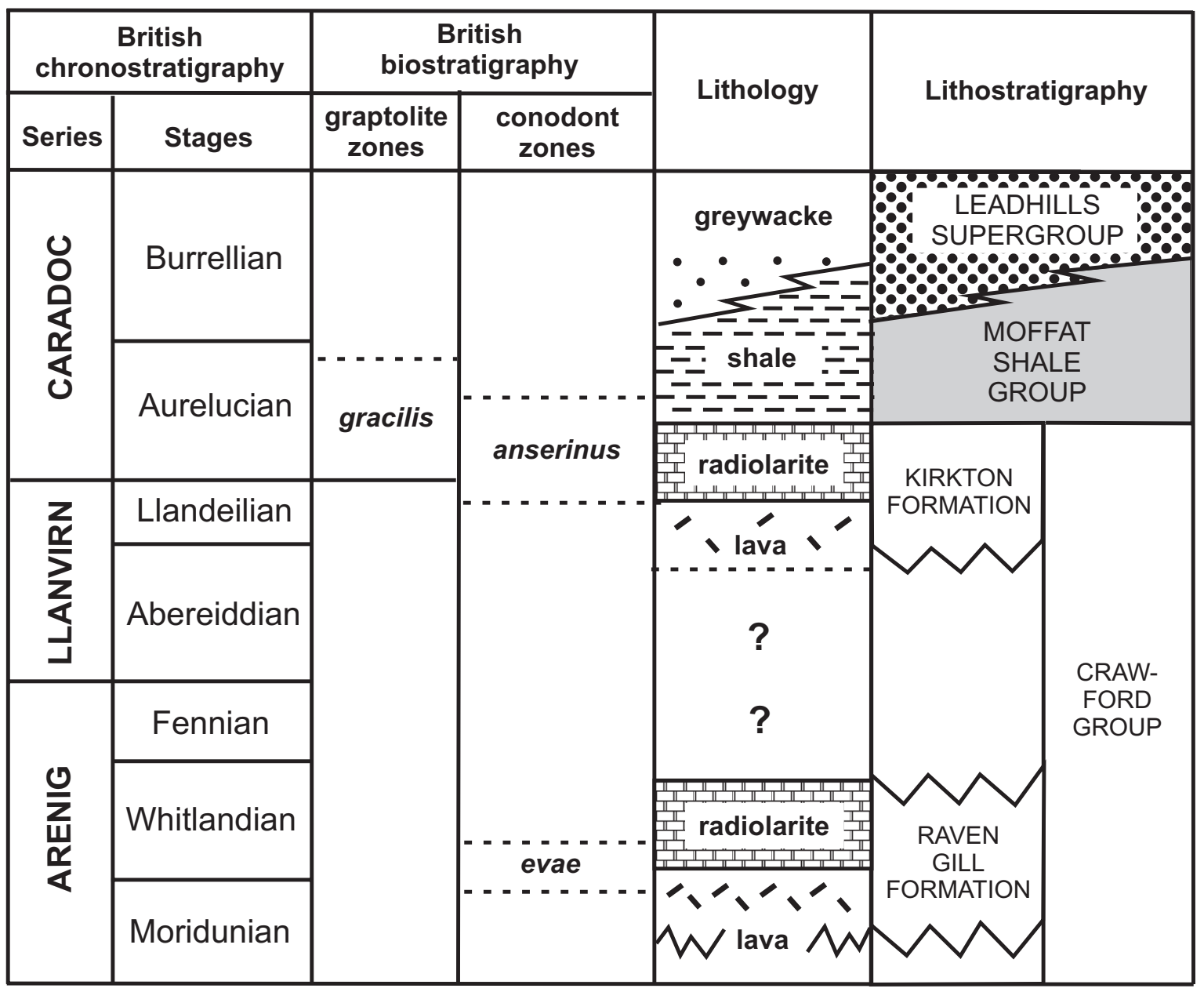

Armstrong et al. Figure 2 
Raven Gill

(BGS locality JF 176)

[NS 9204 1989]
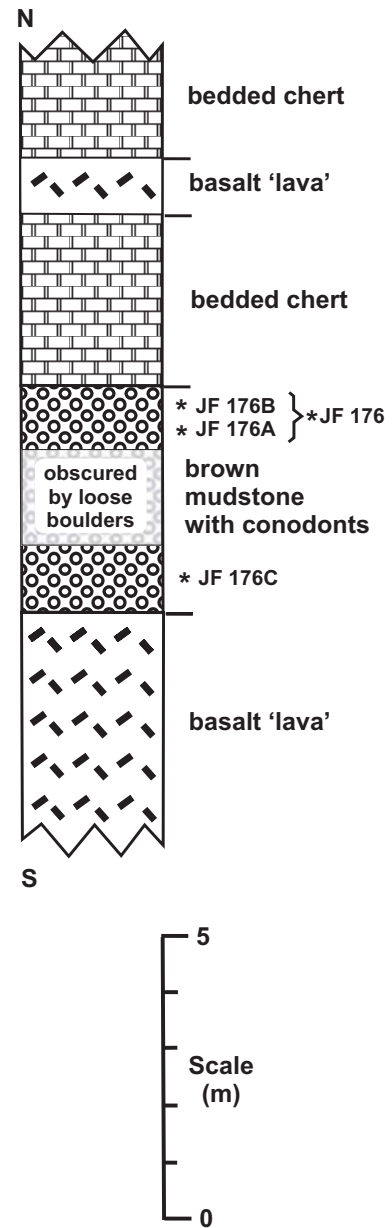

Glencaple Burn

(BGS locality JF 175)

[NS 9255 1989]

Castle Hill

(BGS locality JF 166)

[NS 9373 2175]

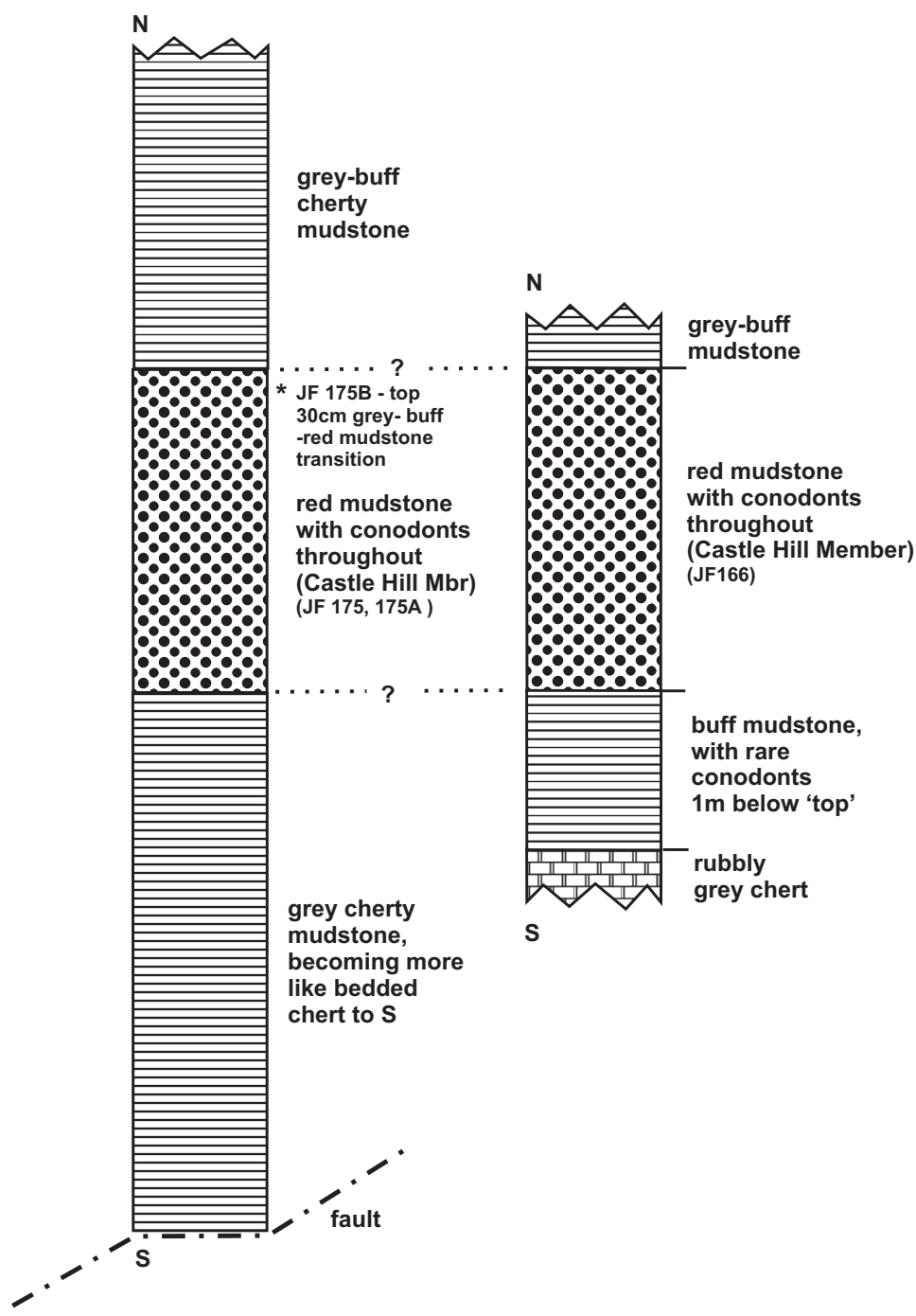

Armstrong et al. Figure 3 


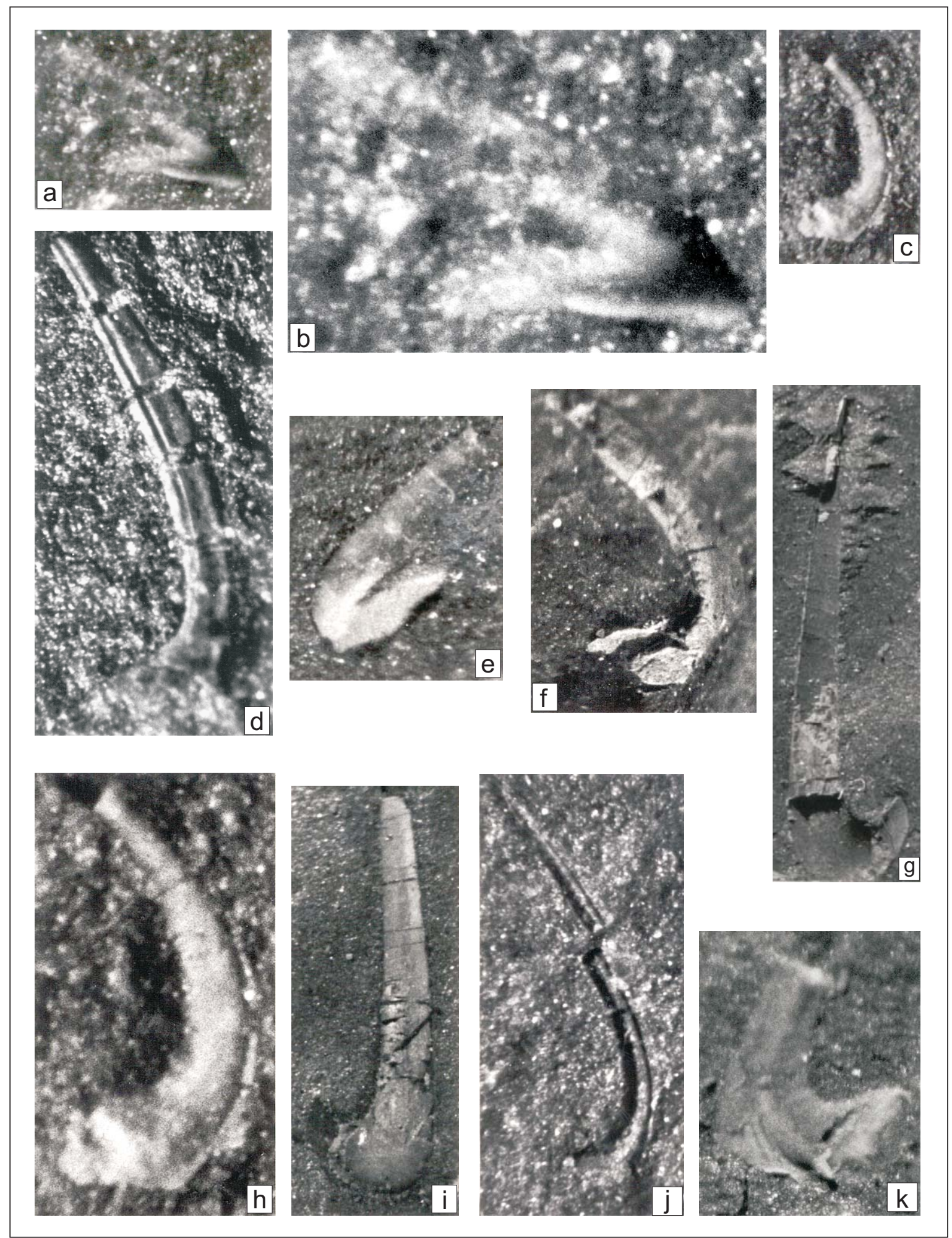

Armstrong et al. Figure 4 


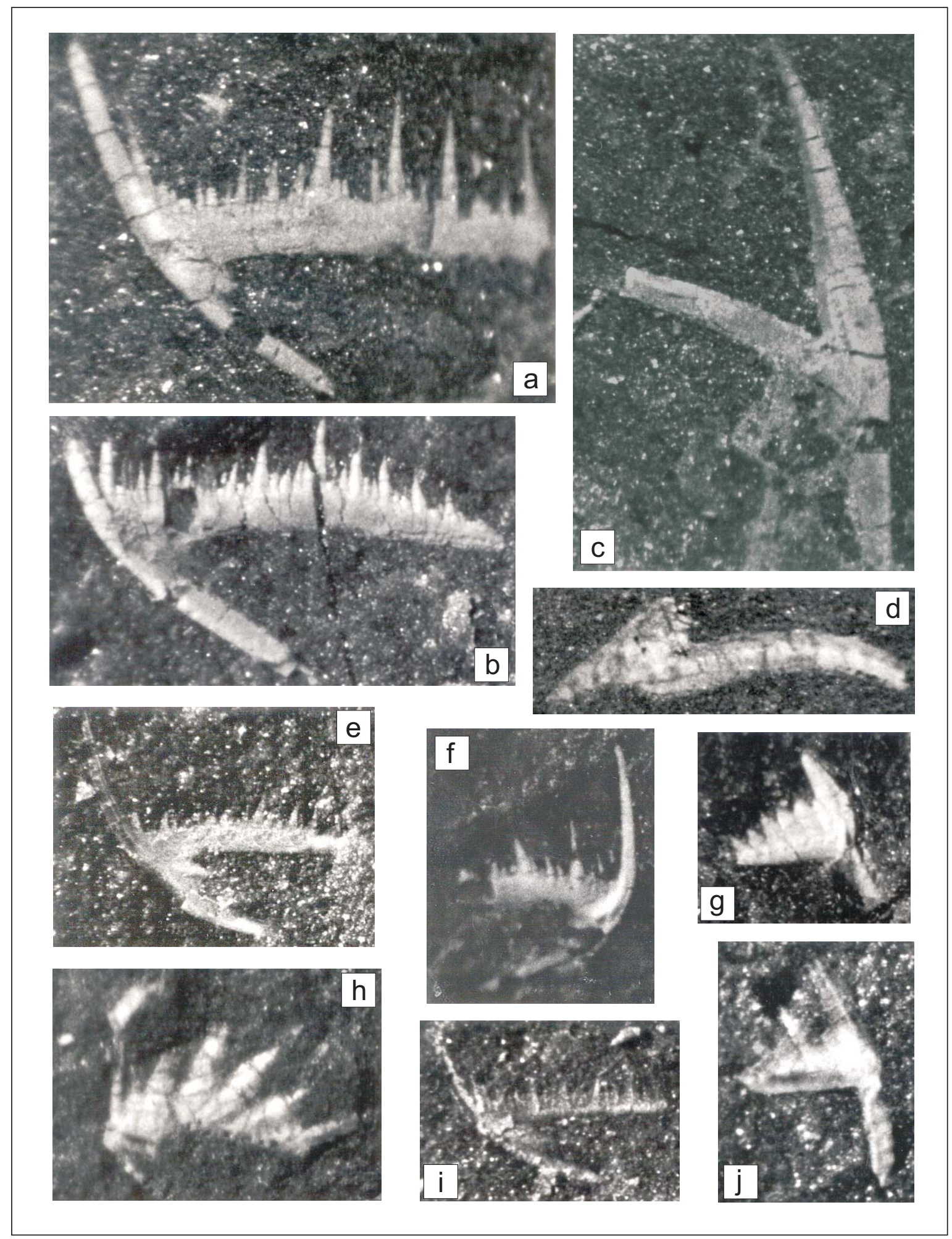

Armstrong et al. Figure 5 


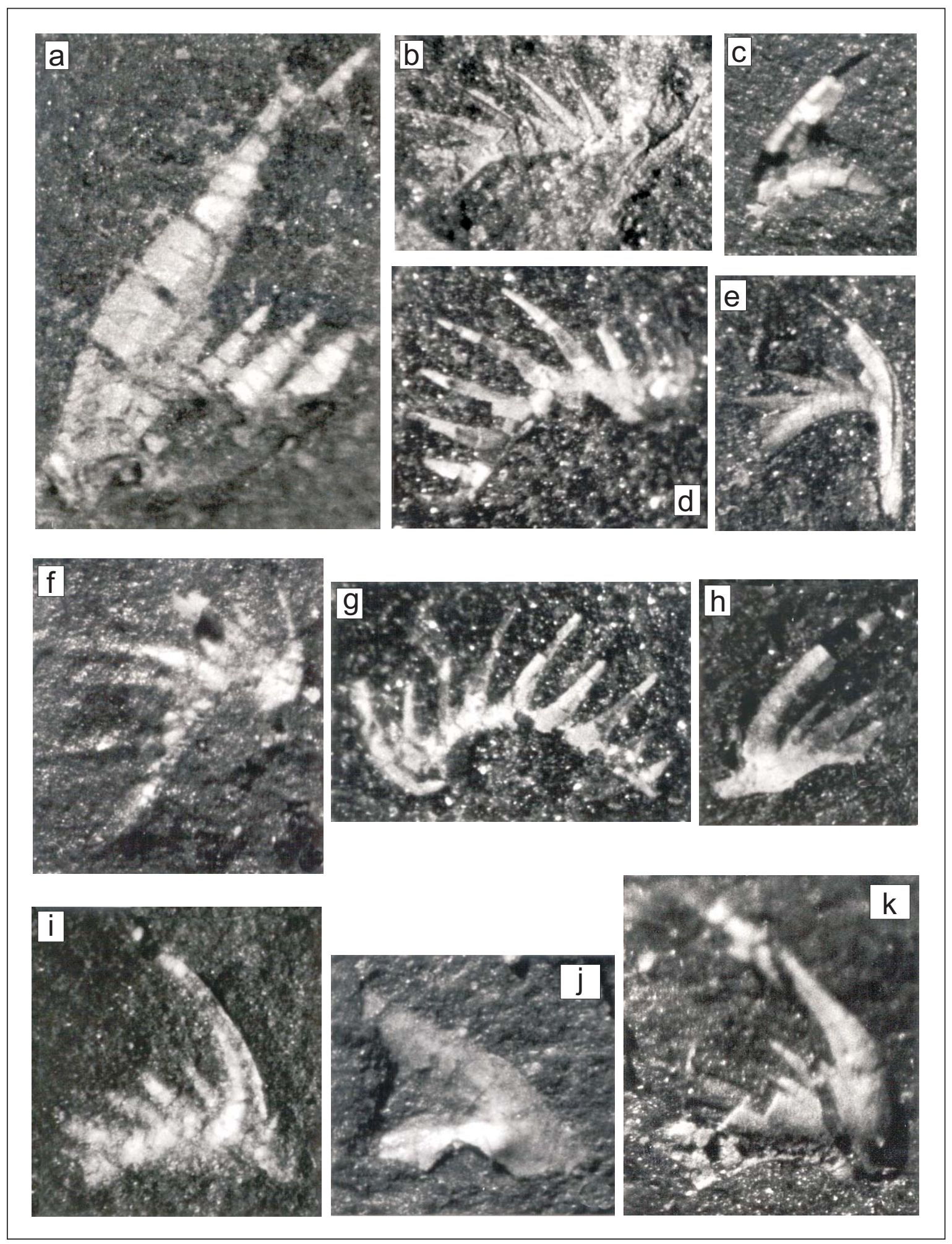

Armstrong et al. Figure 6 


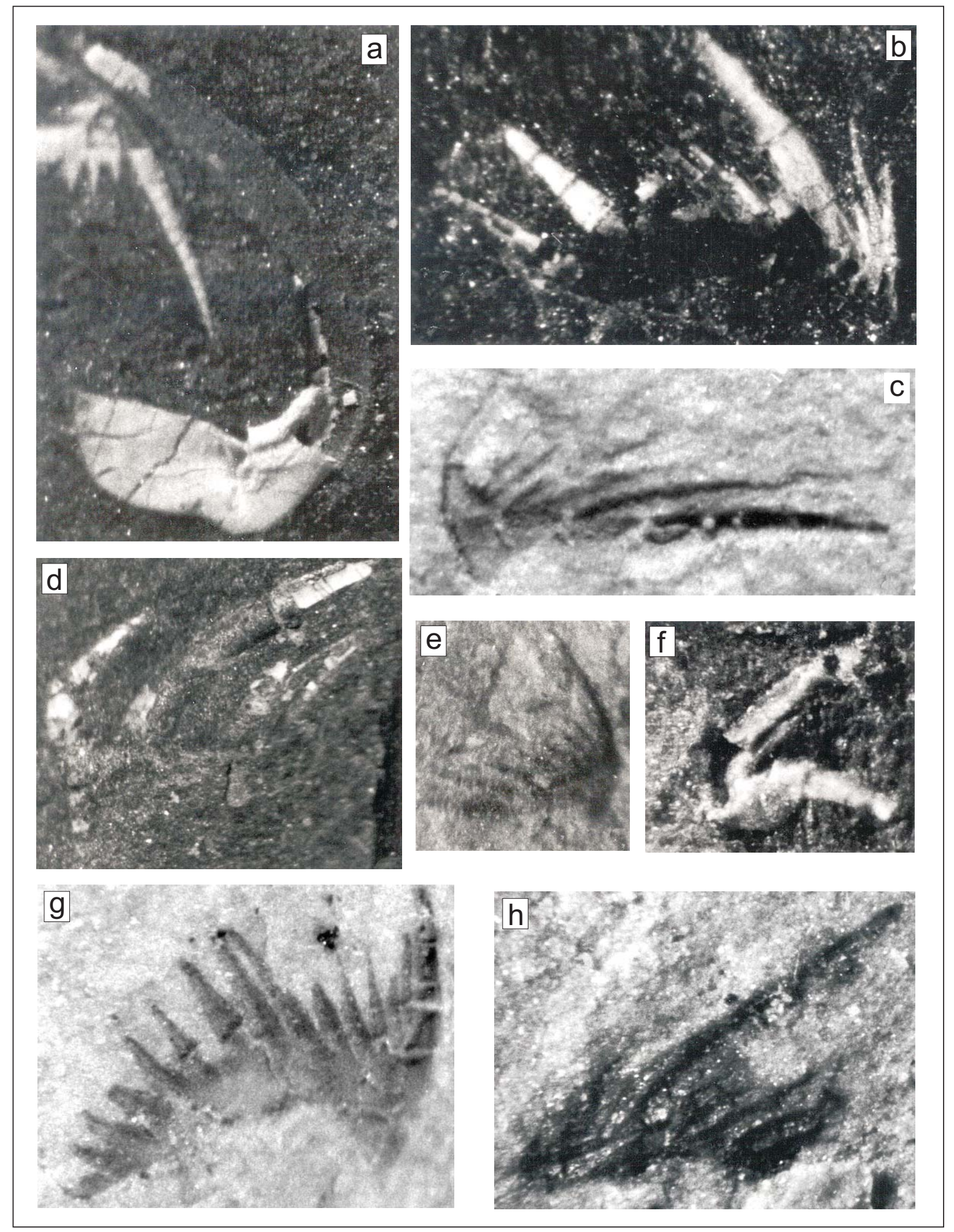

Armstrong et al. $\quad$ Figure 7 


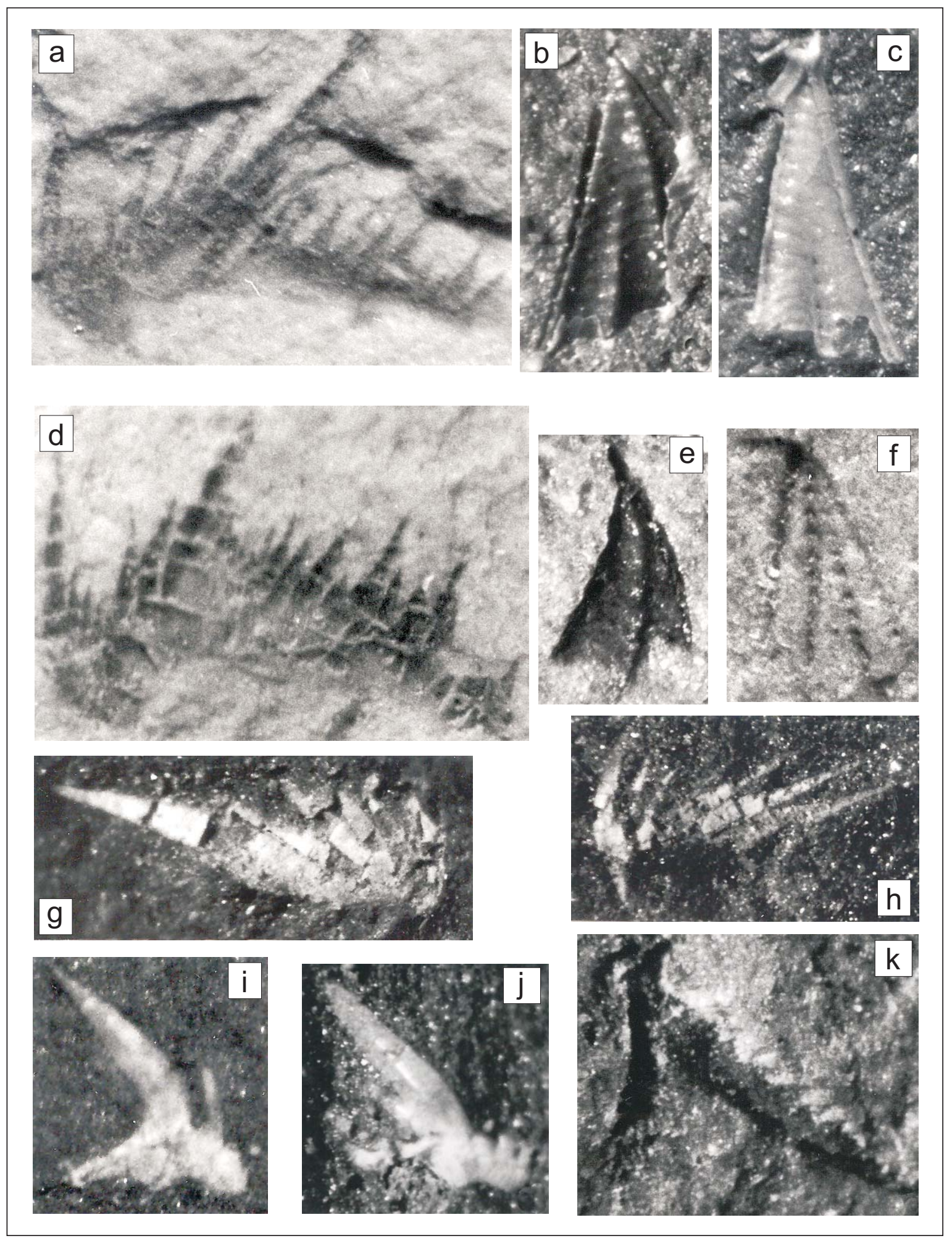

Armstrong et al. Figure 8 